\title{
LOCAL WISDOM: CAN IT MITIGATE THE RISK OF FRAUD?
}

\author{
Yosua Febrian Putra Aditya ${ }^{1}$, Aprina Nugrahesthy Sulistya Hapsari ${ }^{2}$ \\ 1 Universitas Kristen Satya Wacana, Salatiga - Indonesia \\ 2 Universitas Kristen Satya Wacana, Salatiga - Indonesia \\ yosuafpa@gmail.com
}

INFO ARTIKEL ABSTRAK/ABSTRACT

Histori Artikel :
Tgl. Masuk : 27-02-2020
Tgl. Diterima : 10-03-2020
Tersedia Online : 20-04-2020

Tersedia Online : 20-04-2020

Keywords:

Village Fund, Fraud Risk, Local Wisdom

\begin{abstract}
The risk of fraud in managing village funds is increasingly proportional to the increasing amount of funds provided by the central government every year. One of the ways that the government can use to mitigate the risk of fraud is to implement local wisdom. This research was conducted to identify the fraud risk that occurs in managing village funds in Kebonan Village and analyze local wisdom as one of the media to mitigate fraud in the management of village funds in the village. This research uses descriptive qualitative data method with primary data sources. The instrument used in the study was a semi-structured interview. The result of this study shows that even though there is already control to reduce and manage every fraud risk, local wisdom also can be used as a means of mitigating the fraud risk if it is properly imbued.
\end{abstract}

\section{PENDAHULUAN}

Korupsi menjadi salah satu masalah besar yang dihadapi oleh pemerintah di berbagai negara. Survei tahunan yang dilakukan oleh Transparency International (TI) tahun 2018 pada 180 negara dunia menyatakan bahwa masih banyak negara yang terlibat kasus korupsi dan negara di Asia Pasifik dinilai rentan terjadi kasus ini (Muliana, 2018). Indonesia sendiri mendapatkan Indeks Persepsi Korupsi (IPK) dengan skor 38 dan berada pada peringkat 89 tingkat dunia.

Sejak masa reformasi, kasus korupsi di Indonesia mulai menyebar dan berkembang bukan hanya di pemerintahan pusat melainkan terjadi pada tingkatan pemerintahan daerah. Menurut data yang ada di Komisi Pemberantasan Korupsi (KPK) dari tahun 2004 sampai dengan tahun 2018 kasus korupsi di Indonesia tercatat fluktuatif dan dominan meningkat dari tahun ke tahun seperti yang nampak dalam Gambar 1.

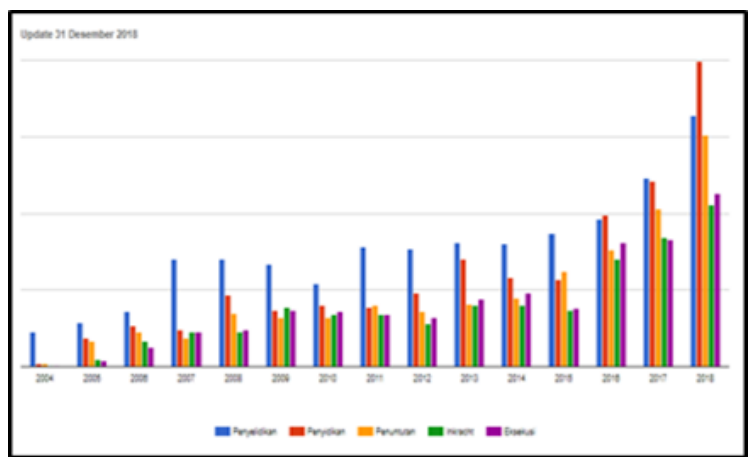

Sumber: Komisi Pemberantasan Korupsi (2018)

Gambar 1. Kasus Korupsi di Indonesia, Tahun 2004-2018.

Indonesian Corruption Watch (ICW) mencatat sektor pengelolaan anggaran desa sebagai penyumbang kasus korupsi terbesar daripada sektor yang lain sekaligus menjadi salah satu yang terbesar dalam menyumbang kerugian negara pada tahun 2018. Sejak dikucurkan pada tahun 2015 , kasus korupsi dana desa yang terjadi terus meningkat dua kali lipat dari tahun ke tahun. Pada 2015, kasus korupsi yang terjadi berjumlah 17 kasus kemudian mengalami peningkatan menjadi 41 kasus 
pada 2016. Tahun 2017 melonjak menjadi 96 kasus. Total kasus dari tahun 2015 sampai dengan semester 1 tahun 2018 mencapai 181 kasus dan 141 kepala desa ditetapkan sebagai tersangka (Ihsanuddin, 2018). Kasus ini meningkat berbanding lurus dengan peningkatan jumlah dana desa yang diberikan oleh pemerintah pusat setiap tahunnya melalui Anggaran Pendapatan Belanja Nasional (APBN) seperti yang ada pada Gambar 2 .

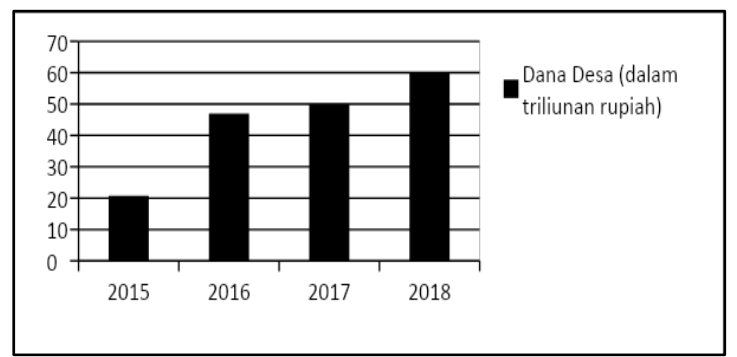

Sumber: Kementerian Keuangan Republik Indonesia (2018)

Gambar 2. Anggaran Dana Desa di Indonesia, Tahun 2015-2018.

Kerugian terbesar di sektor infrastruktur dilakukan oleh Kepala Desa Olung Balo, Kabupaten Mulung Raya, Kalimantan Tengah, mencapai 441 juta rupiah yang mulanya ditujukan untuk pembangunan empat jembatan baru di desa tersebut (Adzkia, 2019). Kasus korupsi dana desa tersebut menunjukkan adanya penyelewengan tujuan awal pengalokasian dana desa yaitu untuk mencapai keberhasilan pembangunan nasional yang dimulai dari pemerintahan daerah terkecil yaitu desa (Fajri et al., 2015). Hal lain yang mendukung adanya pengguliran dana desa ini adalah Nawacita Presiden Joko Widodo khususnya terkait dengan pembangunan Indonesia dari pinggiran, bukan hanya sekedar pinggiran kota melainkan secara langsung masuk ke pedesaan. Dana desa memiliki tujuan dalam meningkatkan pelayanan publik di desa, mengentaskan kemiskinan, memajukan perekonomian, mengatasi masalah kesenjangan pembangunan yang terjadi antar desa, serta memperkuat masyarakat desa sebagai subjek pembangunan (Kementerian Keuangan Republik Indonesia, 2017). Oleh karena itu peran masyarakat dan lembaga untuk penyelenggaraan pemerintahan desa harus dilaksanakan secara baik mulai dari perencanaan hingga pengawasan sebagai bagian dari pertanggungjawaban realisasi dana desa sehingga tidak ada kebijakankebijakan yang menyimpang (Taufik, 2013).

Pasal 81 ayat (4) Undang-Undang No. 6 Tahun 2014 Tentang Desa menegaskan bahwa setiap pembangunan berskala desa dilaksanakan sendiri oleh desa. Di lain sisi, UU ini mengakibatkan potensi resiko yang besar karena banyak desa yang belum mengetahui tata cara pengelolaan dana desa (Wibisono, 2018). Kelemahan ini rawan dimanfaatkan oleh pihak yang seharusnya dapat dipercaya oleh masyarakat untuk melakukan tindak kecurangan terhadap pengelolaan dana desa sehingga penggunaannya tidak tepat sasaran. Sebagai contoh di Kabupaten Konawe, Sulawesi Tenggara terdapat tiga desa yang mendapatkan dana desa mencapai lima miliar rupiah sepanjang tahun 2015-2018 namun pada pencatatan pemerintah pusat zona administratifnya tidak pernah ditemukan (Fauzi, 2019). Di Kabupaten Kendal, Jawa Tengah, terdapat tiga pemegang kekuasaan tertinggi di desa tersangkut kasus korupsi dana desa (Wenden, 2011). Penyebab terjadinya kasus tersebut adalah kurangnya pengawasan yang dilakukan oleh pihak masyarakat dan pemerintah. Sementara itu Atmadja dan Saputra (2017) juga menyebutkan bahwa masih banyak potensi kecurangan yang terdapat pada 57 desa yang menerima dana desa di Kabupaten Buleleng, Bali. Hal ini disebabkan karena adanya perilaku dari pimpinan maupun staf dalam organisasi tersebut yang tidak sesuai dengan pedoman. Penelitian lain yang dilakukan oleh Rahayu et al. (2018) di pemerintahan desa wilayah Polanharjo, penyebab terjadinya fraud dapat dipengaruhi oleh kompetensi aparatur pemerintah desa serta pengendalian internal pada pengelolaan keuangan desa.

Kecurangan dapat dimitigasi melalui berbagai cara salah satunya dengan mengimplementasikan kearifan lokal (Saputra et al., 2018). Kearifan lokal adalah 
norma dan nilai-nilai sosial yang mengatur tentang pembangunan keseimbangan antara daya dukung lingkungan alam dengan gaya hidup dan kebutuhan manusia (Pattinama, 2009). Penelitian tersebut menjelaskan bahwa pawongan sebagai contoh kearifan lokal masyarakat Bali dapat memitigasi kecurangan dengan mewajibkan aparatur untuk mempertanggungjawabkan realisasi anggarannya kepada masyarakat melalui publikasi anggaran tahunannya. Kemudian penelitian yang dilakukan oleh Darmada et al. (2015) menyatakan bahwa masyarakat di Desa Penarukan dalam membuat laporan keuangan sudah terintegrasi dengan memaknai kearifan lokal Pade Gelahang yang memupuk rasa kebersamaan tanpa melihat latar belakang dan menjadi akar dalam mempererat hubungan antar anggota organisasi. Di Jawa, khususnya Jawa Tengah kearifan lokal masih sangat melekat dalam kehidupan bermasyarakat sehari-hari, misalnya budaya merti dusun yang memiliki tujuan memagari desa dari hal-hal yang bersifat negatif serta meningkatkan solidaritas sosial.

Berdasarkan latar belakang tersebut, penelitian ini bertujuan untuk mengidentifikasi risiko kecurangan yang terjadi dalam pengelolaan dana desa di Desa Kebonan dan melakukan analisis terkait kearifan lokal sebagai salah satu bentuk sarana untuk memitigasi adanya kecurangan dalam pengelolaan dana desa di Desa Kebonan. Alasan pemilihan Desa Kebonan dalam penelitian ini adalah desa tersebut merupakan salah satu penerima dana desa dari APBN sejak tahun 2015, mendukung visi dan misi Kabupaten Boyolali salah satunya bersih dan berintegritas, serta kearifan lokal yang ada masih terus dijunjung tinggi oleh masyarakat desa ditunjukkan dengan pelaksanaan merti desa di setiap tahun sebagai rasa ucapan syukur masyarakat kepada Sang Pencipta karena sudah diberikan kelimpahan dan dijauhkan dari hal-hal negatif. Manfaat dari penelitian ini bagi perangkat Desa Kebonan sebagai sarana evaluasi pengendalian internal perangkat desa dan masyarakat supaya lebih bijaksana dalam mengelola keuangan desa dan dapat digunakan secara optimal, mendorong masyarakat Desa Kebonan untuk terus melestarikan kearifan lokal yang ada karena melihat dampak positif dari kearifan lokal dalam memitigasi risiko kecurangan pengelolaan keuangan desa, serta sebagai literatur bagi peneliti selanjutnya.

\section{KERANGKA TEORITIS}

\section{Dana Desa}

Desa adalah kesatuan masyarakat hukum yang memiliki kewenangan mengatur dan mengurus kepentingan masyarakat setempat berdasarkan asalusul dan adat istiadat yang diakui dalam sistem pemerintahan nasional dan berada di daerah kabupaten (Amalia dan Syawie, 2015). Sejak tahun 2015, dalam rangka pemerataan pembangunan di Indonesia, desa menjadi salah satu tujuan Presiden Joko Widodo. Hal ini dinyatakan dengan komitmen pemerintah untuk menggulirkan dana desa. Menurut Pasal 1 angka 2 Peraturan Pemerintah No. 8 Tahun 2016 Tentang Dana Desa menjelaskan bahwa dana desa adalah dana yang bersumber dari APBN yang diperuntukkan bagi desa dan ditransfer melalui APBD kota/kabupaten serta digunakan untuk membiayai penyelenggaraan pemerintahan, pelaksanaan, pembangunan, dan pemberdayaan masyarakat. Berdasarkan Peraturan Menteri Dalam Negeri No. 20 Tahun 2018 Tentang Pengelolaan Keuangan Desa, juga menyampaikan bahwa pengelolaan keuangan desa adalah keseluruhan kegiatan yang meliputi: perencanaan, pelaksanaan, penatausahaan, pelaporan, dan pertanggungjawaban.

Perencanaan merupakan proses pemikiran dan penentuan dalam kegiatan pembangunan infrastruktur dan pemberdayaan masyarakat desa untuk mencapai tujuan dari pengelolaan keuangan desa (Abidin, 2015). Pemerintah desa memiliki kewenangan dalam menyusun perencanaan pembangunan desa didasarkan pada perencanaan 
pembangunan yang ada di kabupaten/kota. Perencanaan pembangunan desa wajib dilaksanakan dengan melibatkan masyarakat dalam musyawarah perencanaan pembangunan desa (musrenbangdes) yang diikuti oleh Badan Permusyawaratan Desa (BPD) untuk menjadi pedoman dalam menyusun Rencana Pembangunan Jangka Menengah Desa (RPJMDes) untuk jangka waktu enam tahun dan Rencana Kerja Pemerintah Desa (RKPDes) yang digunakan sebagai dasar pembuatan Anggaran Pendapatan dan Belanja Desa (APBDes).

Masuk ke dalam tahap pelaksanaan keuangan desa yang telah ditetapkan untuk kegiatan pemerintahan desa dalam pelaksanaan pembangunan desa, pelayanan, pembinaan maupun pemberdayaan masyarakat desa disertai dengan bukti yang lengkap dan sah dimulai dari pelaksanaan kegiatan dengan Rencana Anggaran Biaya (RAB) sampai dengan diterimanya bukti pembayaran dari penyedia barang/jasa. Dalam merealisasikan keuangan desa yang bertanggung jawab sebagai koordinator kegiatan yang dilakukan oleh perangkat dan masyarakat desa sebagai Tim Pelaksana Kegiatan (TPK) adalah kepala desa dibantu dengan pendamping secara berjenjang. Pemanfaatan sumber daya manusia dan alam, serta daya guna swadaya maupun gotong royong masyarakat harus menjadi prioritas dalam pelaksanaan kegiatan.

Penatausahaan pengelolaan dan pencatatan oleh bendahara desa atas semua kegiatan dan pelaksanaan keuangan desa yang telah ditetapkan oleh kepala desa melalui keputusan kepala desa. Formulir atau daftar yang dipergunakan meliputi: buku kas umum, buku kas pembantu pajak, dan buku bank. Bendahara desa diwajibkan untuk mempertanggungjawabkan uang melalui laporan pertanggungjawaban yang akan disampaikan kepada kepala desa setiap bulan dan paling lambat pada tanggal 10 bulan berikutnya.
Pelaporan atas realisasi penggunaan keuangan desa wajib dilaksanakan oleh pemerintah desa melalui kepala desa kepada Bupati/Walikota. Dalam Pasal 103 Peraturan Pemerintah No. 43 Tahun 2014 Tentang Desa menyatakan bahwa laporan tersebut dilaksanakan dua kali yaitu pada semester pertama disampaikan paling lambat pada bulan Juli tahun berjalan dan pada semester kedua disampaikan paling lambat akhir bulan Januari tahun berikutnya. Laporan Pertanggungjawaban Realisasi Pelaksanaan APBDesa merupakan bagian tidak terpisahkan dari Laporan Penyelenggaraan Pemerintahan Desa (LPPD).

Pertanggungjawaban yang dibahas bersama dengan BPD kemudian diserahkan kepada Bupati/Walikota dalam bentuk rancangan peraturan desa tentang pertanggungjawaban pelaksanaan keuangan desa kemudian ditetapkan sebagai peraturan desa disertai dengan keputusan kepala desa mengenai keterangan pertanggungjawaban kepala desa. Laporan pertanggungjawaban paling lambat disampaikan sebulan setelah akhir tahun anggaran bersangkutan.

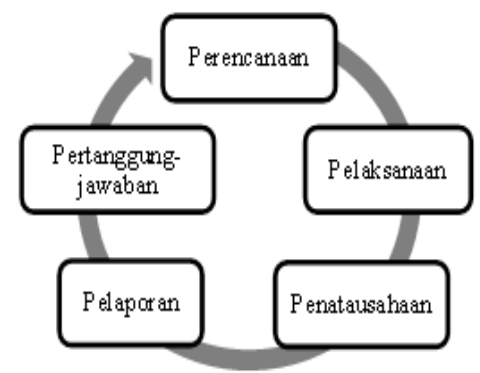

Sumber: Badan Pengelolaan Keuangan dan Aset (2016)

Gambar 3. Tahapan Pengelolaan Keuangan Desa.

\section{Kecurangan (Fraud)}

Menurut Association of Certified Fraud Examiners (2018), salah satu asosiasi di Amerika Serikat yang melakukan usaha pencegahan dan pemberantasan kecurangan akuntansi mendefinisikan fraud adalah perbuatan-perbuatan menentang hukum yang dilakukan secara sengaja oleh orang-orang di dalam maupun luar organisasi seperti manipulasi data dan 
memberikan laporan palsu kepada pihak lain untuk mendapatkan keuntungan pribadi atau kelompok yang secara langsung atau tidak langsung merugikan pihak lain. Sementara itu menurut Statement on Auditing Standards No.99 fraud merupakan sebuah tindakan disengaja yang mengakibatkan salah saji material dalam laporan keuangan yang menjadi subjek dari audit.

Berdasarkan perbuatannya, ACFE mengkategorikan kecurangan dalam tiga kelompok yaitu: (1) asset misappropriation meliputi pencurian atau penyalahgunaan aset perusahaan maupun pihak lain. Kecurangan seperti ini sangat mudah untuk dideteksi karena sifatnya yang tangible dan dapat diukur, (2) fraudulent statements, tindakan yang dilakukan oleh pejabat atau eksekutif perusahaan maupun instansi pemerintah dalam merekayasa penyajian laporan keuangan untuk menutupi kondisi keuangan yang sesungguhnya supaya mendapatkan keuntungan, (3) corruption yang sering kali tidak dapat dideteksi karena para pihak yang bekerja sama menikmati keuntungan atau adanya simbiosis mutualisme.

Dalam fraud triangle atau segitiga kecurangan yang pertama kali diciptakan oleh Cressey (1953) terdapat tiga faktor yang menjadi penyebab kecurangan akuntansi yaitu: (1) rasionalisasi (rationalization), yaitu adanya sikap, karakter, dan nilai-nilai etis yang memperbolehkan pihak-pihak tertentu untuk melakukan tindakan kecurangan atau orang-orang yang berada di sekitar lingkungan organisasi maupun pihak-pihak yang menekan untuk merasionalkan tindakan kecurangan, (2) tekanan (pressure), adanya intensif atau kebutuhan seseorang untuk melakukan tindakan kecurangan. Tekanan dapat berupa gaya hidup, tuntutan pekerjaan, tuntutan ekonomi dan lain-lain yang termasuk dalam bidang keuangan maupun non keuangan, (3) kesempatan (opportunity), situasi yang membuka kesempatan bagi pihak-pihak tertentu melakukan tindakan kecurangan.

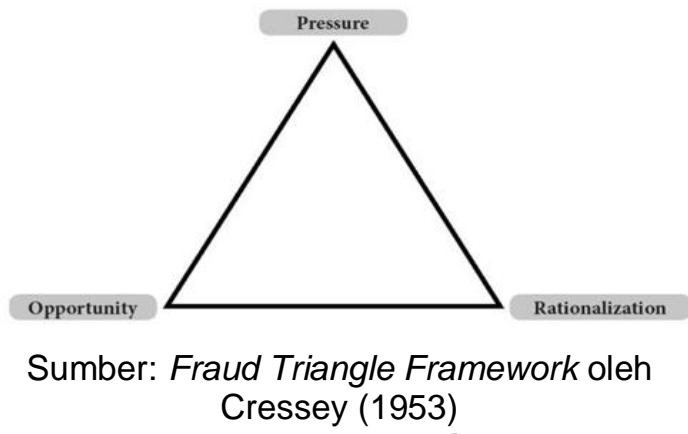

Gambar 4. Fraud Triangle.

\section{Kearifan Lokal}

Kearifan lokal sebagai pemitigasi risiko kecurangan merupakan pandangan hidup dan ilmu pengetahuan serta berbagai strategi kehidupan yang dilakukan oleh masyarakat yang hidup di suatu tempat tertentu dalam menjawab berbagai permasalahan yang dihadapi untuk pemenuhan kebutuhan mereka (Fajarini, 2014). Sedangkan Pawarti et al. (2012) mendefinisikan kearifan lokal sebagai salah satu warisan budaya yang ada dan turuntemurun dilaksanakan oleh masyarakat yang berada pada daerah tertentu dengan memanfaatkan sumber daya alam secara berkelanjutan. Menurut Sartini (2004) kearifan lokal memiliki beberapa fungsi seperti: (1) berfungsi untuk konservasi dan pelestarian sumber daya alam, (2) mengembangkan sumber daya manusia, (3) mengembangkan kebudayaan dan ilmu pengetahuan, (4) berfungsi sebagai petuah, kepercayaan, sastra dan pantangan bagi masyarakat lokal.

Di Indonesia sangat majemuk dan mempunyai beragam suku dan kebudayaan yang menjadi bagian dari kearifan lokal. Sebagai contoh di Kabupaten Dharmasraya sebagai bagian wilayah dari Provinsi Sumatera Barat yang memiliki budaya yang dikenal dengan petitih alam takambang manjadi guru dengan menganggap alam sebagai guru dalam menjalani kehidupan sehari-hari (Pawarti et al., 2012). Kemudian masyarakat Baduy, Provinsi Banten masih memegang teguh kearifan lokalnya seperti salah satu pikukuh lojor teu meunang dipotong, pondok teu meunang disambungan yang mempunyai makna tidak mengubah sesuatu dengan 
menambah atau mengurangi apa yang sudah ada serta apabila ada masyarakat yang melanggar pikukuh ini akan memperoleh sanksi dari puun atau pimpinan adat tertinggi masyarakat Baduy (Permana et al., 2018). Contoh lain ada di Jawa Tengah yang melakukan upacara adat saparan dan merti desa. Saparan dilakukan setiap bulan sapar menurut kalender Jawa. Ritual saparan atau yaqowiyu di Klaten misalnya, muncul pertama kali berbentuk majelis pengajian yang dikunjungi umat Islam dan masyarakat sekeliling Jatinom untuk mengingat cikal bakal Jatinom yaitu Kyai Ageng Gribiq yang merupakan tokoh penyebar agama Islam (Islami, 2014). Selanjutnya Sulistyaningsih dan Badraningsih (2017) mengungkapkan bahwa di Dusun Pulesari, Desa Wonokerto, Kabupaten Sleman melakukan merti desa sebagai salah satu rangkaian acara saparan yang diadakan pada hari Rabu terakhir di bulan jawa, yaitu bulan sapar. Merti desa merupakan merupakan upacara syukuran atau slametan atas keberkahan dan kelimpahan yang telah didapat oleh warga. Adanya kegiatan bersih desa dalam salah satu ritual merti desa memiliki makna membersihkan desa dari hal-hal kotor/negatif supaya dapat menjadi desa yang bersih dari hal-hal negatif. Apabila terdapat ritual merti desa yang tidak dilakukan oleh masyarakat, diyakini desa akan mengalami malapetaka di masa yang akan datang. Kearifan lokal tersebut diharapkan dapat mengurangi adanya risiko-risiko kecurangan sebagai salah satu hal yang diduga tidak baik dalam desa.

\section{METODOLOGI PENELITIAN}

\section{Jenis Penelitian dan Teknik Pengumpulan Data}

Jenis penelitian ini merupakan penelitian deskriptif kualitatif karena di dalamnya menjelaskan tentang gambaran peristiwa atau kejadian secara fakta, sistematis dan akurat yang berada di Desa Kebonan, Kabupaten Boyolali yang diharapkan dapat menganalisis dan mengkaji secara deskriptif mendetail terkait risiko kecurangan yang dapat terjadi. Data yang didapatkan langsung berasal dari narasumber seperti kepala desa, sekretaris desa, serta bendahara desa, dengan konfirmasi dari masyarakat Desa Kebonan melalui wawancara, sehingga data yang digunakan dalam penelitian ini adalah data primer. Wawancara semi terstruktur yang menjadi teknik pengumpulan data dalam penelitian ini menggunakan panduan wawancara yang dapat dikembangkan ketika wawancara berlangsung untuk menggali informasi lebih mengenai risiko kecurangan yang dapat terjadi dikaitkan dengan kearifan lokal yang ada di Desa Kebonan didukung dengan catatan, alat perekam suara, dan dokumentasi.

Teknik analisis data yang digunakan dalam penelitian ini yaitu reduksi data, penyajian data, dan penarikan kesimpulan. Reduksi data bertujuan untuk menghilangkan data yang tidak perlu untuk menjawab pertanyaan-pertanyaan peneliti terkait risiko kecurangan dengan kearifan lokal sebagai pemitigasinya. Reduksi data dimulai dengan meringkas dan memusatkan perhatian pada data-data yang telah didapatkan di lapangan yang berasal dari narasumber. Selanjutnya penyajian data dilakukan dengan mengklasifikasikan kumpulan informasi berdasarkan pokok permasalahan tentang risiko kecurangan dengan kearifan lokal sebagai pemitigasinya, supaya peneliti dapat melihat secara keseluruhan maupun bagian tertentu untuk menarik kesimpulan. Penarikan kesimpulan merupakan tahapan akhir dari analisis data yang dilakukan oleh peneliti dengan mengambil inti dari data yang telah terkumpul kemudian menjelaskannya untuk menemukan arti atau makna data dalam menjawab rumusan masalah penelitian. Peneliti melakukan verifikasi kepada beberapa narasumber untuk mengkonfirmasi data selama penelitian ketika berada di lapangan supaya mendapatkan keabsahan data sesuai dengan metoda triangulasi. Model triangulasi yang digunakan dalam penelitian ini adalah jenis triangulasi sumber yaitu dengan membandingkan informasi yang diperoleh melalui sumber yang berbeda seperti membandingkan 
antara hasil wawancara narasumber satu dengan narasumber yang lain, membandingkan hasil wawancara narasumber dengan dokumen, serta membandingkan hasil wawancara narasumber dengan hasil observasi di lapangan.

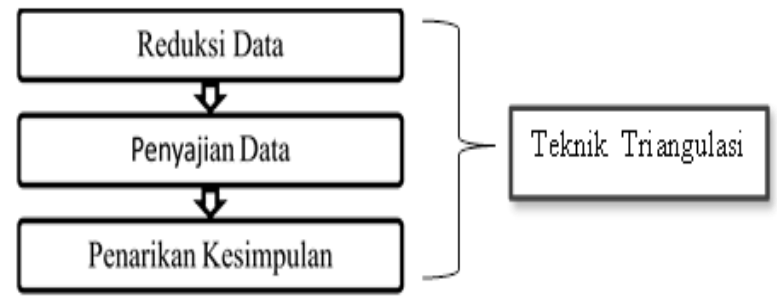

Gambar 4. Teknik Analisis Data.

\section{HASIL DAN PEMBAHASAN}

\section{Gambaran Objek Penelitian}

Desa Kebonan adalah sentral dari pemerintahan, perekonomian dan jasa di Kecamatan Karanggede, Kabupaten Boyolali yang berada pada jalur alternatif transportasi darat antar dua provinsi yaitu Jawa Tengah dan Jawa Timur. Desa ini memiliki luas wilayah $165 \mathrm{Ha}$ yang menurut penggunaannya meliputi: (1) tanah untuk sawah seluas $95 \mathrm{Ha}$, (2) tanah tegal seluas $6 \mathrm{Ha}$, (3) tanah untuk pekarangan seluas $49 \mathrm{Ha}$, (4) tanah untuk digunakan keperluan lain seluas $15 \mathrm{Ha}$. Secara administratif letak geografis Desa Kebonan di sisi barat berbatasan dengan wilayah Kabupaten Semarang, di sisi timur berbatasan dengan Desa Sendang dan Sranten, di sisi selatan berbatasan dengan Desa Tegalsari, sementara di sisi utara berbatasan dengan Desa Klari. Per Januari tahun 2020, Desa Kebonan yang terdiri dari Dusun Kebonan, Dusun Trayondan Dusun Pulutan diketahui memiliki jumlah penduduk sebesar 4095 jiwa dengan jumlah jenis kelamin laki-laki sebesar 2067 jiwa dan jumlah jenis kelamin perempuan sebesar 2028 jiwa. Mata pencaharian penduduk Desa Kebonan didominasi oleh buruh dan tani.

Sejak tahun 2015, Desa Kebonan menerima dana desa yang diberikan oleh pemerintah pusat melalui APBN. Jumlahnya fluktuatif setiap tahunnya.
Secara rinci, dana desa yang diterima oleh Desa Kebonan tahun 2015 sebesar Rp 264.692.000,00, tahun 2016 sebesar Rp 593.765.000,00, tahun 2017 sebesar Rp 771.702.000,00, tahun 2018 sebesar Rp 684.470.000,00, dan pada akhir tahun 2019 sebesar Rp 770.501.00,00.

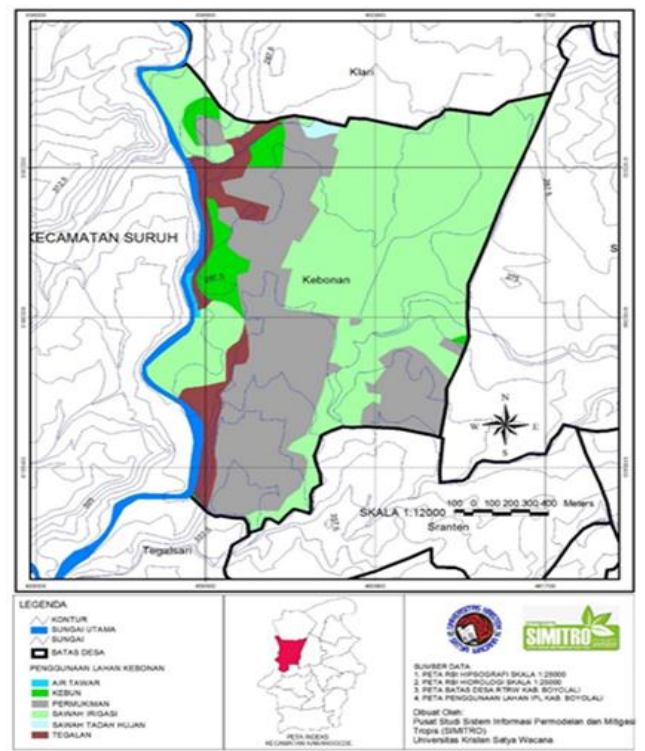

Sumber: Pemerintah Desa Kebonan (2017)

Gambar 5. Peta Penggunaan Lahan Desa Kebonan, Kecamatan Karanggede, Kabupaten Boyolali.

\section{Pengelolaan Dana Desa di Desa Kebonan}

Pengelolaan dana desa di Desa Kebonan dimulai dari tahap perencanaan. Tahap ini diawali dengan adanya musyawarah dusun untuk mengumpulkan kebutuhan masyarakat dan menentukan skala prioritas pembangunan serta akan dijadikan dasar pembahasan di dalam musrenbangdes yang dilaksanakan pada bulan Januari. Kepala desa sebagai pemimpin musyawarah akan mengarahkan pembahasan antara skala prioritas pembangunan dari masyarakat dengan setiap kebijakan yang berlaku di pemerintah kabupaten maupun pusat. Hasil dari musrenbangdes akan dijadikan sebagai dasar penyusunan RKPDes yang merupakan penjabaran dari RPJMDes untuk melakukan pengajuan rancangan APBDes kepada bupati melalui camat. Namun jika terdapat evaluasi dari camat mengenai rancangan APBDes, maka 
rancangan anggaran tersebut akan dikembalikan lagi ke desa untuk diperbaiki. Setelah APBDes disahkan, perangkat desa menginformasikannya kepada masyarakat melalui pemasangan MMT, flyer, dan melakukan update data di website.

Masuk ke tahap selanjutnya yaitu pelaksanaan dengan pembentukan TPK Desa Kebonan yang terdiri dari masyarakat maupun perangkat desa yang memiliki tugas untuk melakukan pembangunan, dimulai dari pengadaan barang/jasa hingga selesainya kegiatan pembangunan. Selain itu, TPK juga bertanggung jawab atas setiap bukti kegiatan pembangunan yang nantinya dijadikan dasar oleh bendahara desa dalam menyusun SPJ. Pada tahap juga ini dilakukan pencairan dana desa untuk pelaksanaan pembangunan yang dibagi dalam tiga tahap, yaitu tahap pertama $40 \%$, tahap kedua $40 \%$, dan tahap ketiga 20\%. Desa harus menyampaikan APBDes dan SPJ periode sebelumnya kepada kabupaten melalui camat untuk melakukan pencairan dana desa tahap pertama, kemudian untuk tahap kedua dan ketiga desa harus menyampaikan laporan penyerapan dana desa di tahap sebelumnya minimal sebesar $75 \%$ serta membuat Surat Permintaan Pembayaran (SPP) untuk rekomendasi camat ke kabupaten.

$\begin{array}{ccc}\text { Bendahara } & \text { desa } & \text { yang } \\ \text { bertanggungjawab } & \text { pada } & \text { tahap }\end{array}$ penatausahaan, bertugas untuk melakukan pencatatan berupa buku kas umum, buku pembantu pajak, dan buku bank atas setiap pengelolaan dana desa pada SISKEUDES berdasarkan bukti kegiatan yang diserahkan oleh TPK. Di akhir tahun anggaran dana desa bendahara desa juga bertugas untuk menyusun laporan pertanggungjawaban yang dikonfirmasi oleh sekretaris desa serta mendapatkan otorisasi langsung dari kepala desa.

Kepala desa kemudian menyerahkan laporan penggunaan dana desa yang berupa laporan semester 1 pada bulan Juni, laporan semester 2 pada bulan Januari tahun berikutnya, serta laporan realisasi anggaran dana desa sesuai dengan tahapan pencairannya kepada bupati melalui camat. Selanjutnya di akhir tahun anggaran, laporan pertanggungjawaban realisasi pelaksanaan APBDesa dan SPJ dilaporkan tepat waktu bahkan sebelum batas akhir pelaporan yang telah ditetapkan oleh pemerintah pusat dibuktikan dengan surat serah terima dari desa ke kecamatan.

Selain melaporkannya kepada bupati melalui camat, perangkat desa juga bertanggung jawab untuk menginformasikan setiap rencana dan realisasi pelaksanaan pembangunan yang telah dilakukan selama satu tahun anggaran dana desa kepada masyarakat serta BPD untuk dievaluasi dan diperbaiki di periode selanjutnya. Selain itu, perangkat desa juga memiliki tanggung jawab kepada kabupaten dengan menyerahkan SPJ melalui camat.

\section{Risiko Kecurangan dalam Pengelolaan Dana Desa dan Bentuk Pengendaliannya}

Berdasarkan hasil wawancara di lapangan yang dilakukan pada objek yang diteliti, dihasilkan beberapa temuan meliputi risiko kecurangan pada setiap tahapan pengelolaan dana desa di Desa Kebonan. Bermula pada tahap perencanaan, risiko kecurangan yang mungkin terjadi dikarenakan adanya kepentingan golongan tertentu menjadi prioritas dalam menyusun RKPDes selama satu tahun anggaran sehingga terdapat beberapa kebutuhan masyarakat desa yang tidak terpenuhi karena beberapa perencanaan pembangunan didasarkan pada kepentingan-kepentingan kelompok tertentu. Hal tersebut sesuai dengan pernyataan dari kepala desa yaitu:

"dalam musrenbangdes banyak sekali Mas yang ingin menonjolkan setiap pembangunan yang ada di wilayah mereka masing-masing. Dusun maunya membangun ini dan ini, tapi kembali lagi bagaimana caranya desa untuk mengatasi itu dalam hal pemerataan pembangunan desa. Ya pilihnya tetep yang urgent dulu, Mas." 
Pengendalian yang dilakukan oleh perangkat desa yaitu dengan membuat tim perumus RKPDes mengacu pada RPJMDes melalui keterlibatan langsung dalam masing-masing sasaran seperti Rukun Tetangga (RT), Rukun Warga (RW), karang taruna dan organisasi masyarakat lainnya yang berada di desa untuk merumuskan setiap masalah yang terjadi. Setelah itu dilakukan pengkajian bersama untuk menentukan skala prioritas pembangunan dengan sumber daya tersedia di setiap dusun dalam musrenbangdes yang dihadiri oleh BPD, tokoh masyarakat, ketua RT, ketua RW serta perwakilan dari organisasi masyarakat di desa sehingga setiap rencana pembangunan yang sudah disahkan riil berdasarkan kebutuhan masyarakat.

"bahkan dalam perencanaan juga mereka memiliki beberapa kepentingan Iho dalam dana desa. Desa tidak merencanakan namun ada interupsi untuk melakukan pembangunan ini. Sering juga ada perubahan aturan, regulasi, kebijakan dari atas."

Menurut kutipan wawancara tersebut, risiko kecurangan lain pada tahap perencanaan dikarenakan adanya regulasi dan aturan yang berlaku terkait pengelolaan dana desa menyebabkan beberapa benturan kepentingan antara pemerintah daerah dan masyarakat desa dalam rencana pembangunan desa sehingga pemenuhan kebutuhan masyarakat menjadi kurang maksimal. Bentuk pengendaliannya, perangkat desa melakukan sinkronisasi antara rencana pembangunan yang sudah disepakati menjadi skala prioritas di musrenbangdes dalam bentuk RKPDes sebagai dasar pengajuan APBDes dengan sistem yang diberikan oleh pemerintah pusat yaitu Sistem Keuangan Desa (SISKEUDES). Setelah semua rencana pembangunan diinput ke dalam sistem, pemerintah desa melakukan koordinasi untuk menetapkan rancangan APBDes dengan pemerintah kabupaten melalui camat terkait kegiatan pembangunan yang akan dilaksanakan selama satu periode dan mengakomodir kebutuhan pemerintah daerah untuk selanjutnya dilakukan penyesuaian serta mengadakan sosialisasi kepada masyarakat sebagai bentuk pengawasan dan pengendalian secara langsung dari masyarakat ke perangkat desa.

"dalam pengelolaan dana desa diperlukan seorang leader yang kompeten juga Mas, ketika kapasitasnya tidak mencukupi dan tidak kompeten ya pasti nanti bakal muncul gejolak. Semangat khawatirnya masyarakat sama pemerintah pusat juga tinggi."

Berdasarkan pernyataan dari kepala desa, risiko kecurangan lain pada tahap perencanaan terjadi karena adanya kesan negatif dari masyarakat serta kekhawatiran pemerintah pusat kepada perangkat desa setelah adanya dana desa yaitu disalah gunakan dalam merencanakan pengelolaannya seperti ancaman korupsi, kolusi dan nepotisme. Pengendalian untuk risiko kecurangan tersebut meliputi: (1) perangkat desa melakukan transparansi RKPDes hingga APBDes selama satu periode melalui pemasangan MMT di tempat strategis, mengunggah di website desa Kebonan supaya dapat diakses oleh siapapun, mendatangi rapat dusun dan membahas rencana pembangunan di dusun yang sudah disahkan, serta bekerjasama dengan ketua RT untuk menyebarkan flyer di setiap rapat RT pada awal tahun, (2) menanamkan karakter yang baik kepada perangkat desa dengan membuktikkan kepada masyarakat secara langsung bahwa perangkat desa dapat bekerja jujur dengan orientasi untuk kepentingan bersama.

Pada tahap pelaksanaan terdapat tiga risiko kecurangan yang dapat terjadi di Desa Kebonan. Pertama, TPK dinilai kurang memahami pengelolaan dana desa yang telah disepakati dalam RKPDes serta bukti kegiatan seperti foto dan nota transaksi pengadaan barang/jasa untuk penyusunan surat pertanggungjawaban (SPJ) dikarenakan latar belakang pendidikan yang rendah serta kegiatan lain diluar pembangunan desa. Hal tersebut 
didukung dengan kutipan wawancara berikut:

"Fokusnya TPK dari masyarakat ya cuman pembangunan secara fisik Mas. Materialnya bagaimana dan membutuhkan apa saja untuk pembangunannya? Ya sudah hanya sampai situ. Karena kan kebanyakan masyarakat desa cuman mau hasilnya saja, setelah itu kembali ke pekerjaan masing-masing berdagang karena sedikit juga yang kerja kantoran Mas karena pendidikan juga ta."

Pengendalian yang diterapkan di Desa Kebonan yaitu mendelegasikan tugas dan tanggungjawab sebagai TPK kepada perangkat desa dengan bukti berita acara dan surat keputusan tentang pengangkatan TPK berdasarkan musyawarah pengkajian rumusan masalah di tingkat desa yang disetujui oleh kepala desa serta dilakukan sosialisasi kepada masyarakat sebagai bentuk keterbukaan pemerintah desa dalam pemilihan TPK supaya pada pelaksanaannya masyarakat dapat mengkritisi, mengevaluasi dan memberikan saran konkrit atas kinerja TPK baik dari dimulainya pelaksanaan kegiatan menggunakan RAB sampai dengan diterimanya bukti pembayaran dari penyedia barang/jasa.

"karena ada sumber daya yang kurang dari pencairan dana desa di tahap awal akhirnya TPK menyesuaikan dulu uang yang ada untuk mencairkan dana desa tahap selanjutnya. Padahal kan realisasinya sudah melebihi. Biasanya menggunakan uang lain terlebih dulu Mas untuk menutupi kekurangannya."

Kedua, manipulasi bukti pengadaan barang/jasa oleh perangkat desa sebagai TPK dalam suatu proyek pembangunan desa yang tidak sesuai dengan $R A B$ dan RKPDes. Tindakan pengendaliannya, perangkat desa bekerjasama dengan ketua RT untuk melibatkan masyarakat setempat dalam kegiatan pembangunan sebagai tenaga kerja maupun penyedia barang/jasa serta menjelaskan kepada masyarakat sebagai pelaksana pembangunan terkait dokumen Peraturan Menteri Desa (Permendes), RAB dan RKPDes supaya dapat dimonitoring secara langsung, baik dari sisi pengadaan material hingga pembayaran tenaga kerja.

"dana desa ditransfer ke rekening itu tidak pasti cairnya kapan, biasanya kita melakukan pengadaan barang/jasa dulu baru ada pembayaran, jadi sistemnya nalangi dulu Mas. Pemberitahuannya dilakukan sehari atau dua hari sebelum dana itu cair jadi memang tidak ada rencana dari awal tahun kapan dana akan itu akan ditransfer."

Ketiga, keterlambatan penyelesaian pembangunan infrastruktur desa dikarenakan implementasi waktu pencairan dana desa dari rekening pemerintah pusat ke rekening pemerintah desa pada tahap awal tahun anggaran tidak dapat dipastikan, serta porsi pencairan dana desa dinilai tidak dapat memenuhi kebutuhan pembangunan, misalnya dalam hal pengadaan barang/jasa desa harus melakukan bon kepada pihak penyedia. Pengendalian untuk risiko kecurangan tersebut meliputi: (1) perangkat desa membuat timeline dengan tolok ukur yang jelas atas setiap penyelesaian pembangunan infrastruktur yang akan dilakukan selama satu tahun anggaran di luar jadwal yang sudah ditetapkan oleh pemerintah pusat maupun daerah, terkhusus dalam tahapan awal pencairan dana desa, (2) Pemerintah pusat maupun daerah perlu melakukan observasi langsung melalui kunjungan rutin tiap tahun terkait implementasi tahapan pencairan dana desa yang sudah berjalan berdasarkan evaluasi dan saran di lapangan dari setiap desa dalam penetapan kembali proporsi alokasi dasar pencairan besaran dana desa serta ketepatan waktu di setiap tahapan.

Pada tahap penatausahaan juga terdapat risiko kecurangan yaitu dalam pengelolaan dan pencatatan atas semua kegiatan dan pelaksanaan keuangan desa yang dilakukan oleh bendahara desa di SISKEUDES dengan menggunakan satu user dan password yang diketahui oleh semua perangkat desa sehingga apabila bendahara desa berhalangan untuk 
melakukan penatausahaan dapat digantikan oleh perangkat desa lainnya sesuai dengan tugas pokok dan fungsinya. Didukung dengan penuturan bendahara desa sebagai berikut:

"semua perangkat desa itu tahu Mas soal username dan passwordnya, karena hanya satu username dan password saja untuk satu aplikasi. Kalau dibuka bareng, ya aplikasinya lemot."

Hal ini memungkinkan perangkat desa untuk melakukan kecurangan manipulasi data dalam penatausahaan pada inputnya di SISKEUDES karena user dan password yang digunakan sama seperti milik bendahara desa sebagai penanggungjawab. Pengendalian yang dapat dijalankan meliputi: (1) semua pengelolaan dan pencatatan yang dilakukan di SISKEUDES oleh bendahara desa harus didasarkan pada bukti transaksi asli yang dilampirkan dalam SPJ seperti nota transaksi, foto kegiatan, dan billing pajak. Hal tersebut harus dikoordinasikan langsung kepada kepala urusan umum dan perencanaan pembangunan desa supaya dapat dilakukan verifikasi dengan pihak penyedia barang/jasa, (2) ketika dalam pelaksanaan terdapat selisih penerimaan pembiayaan lebih besar daripada defisit anggaran yang terjadi maka dana tersebut harus masuk ke dalam Sisa Lebih Pembiayaan Anggaran Tahun Berkenaan (SILPA) dan dilaporkan kepada masyarakat pada rapat perubahan APDB di bulan Juni untuk menambah anggaran kegiatan pembangunan lain, (3) semua input data dalam SISKEUDES dilakukan oleh bendahara desa sebagai penanggungjawab dalam tahap penatausahaan dengan otorisasi langsung dari kepala desa, sedangkan perangkat desa lain memeriksa setiap laporan yang telah dibuat oleh bendahara desa sesuai dengan APBDes dan realisasi yang terjadi di lapangan ditunjukkan dengan bukti kegiatan tanpa memiliki hak untuk melakukan input data pada sistem, (4) User dan password ditambahkan kepada masing-masing perangkat desa sehingga mempermudah mendeteksi pengguna yang melakukan update data pada SISKEUDES. "kendalanya kalau pakai sistem online itu mati lampu, jadi ndak bisa kerja kan WiFi juga ndak ada akses internet. Kadang Iho Mas saya pakai HP di rumah untuk hotspot sistemnya supaya tidak terlambat dalam membuat laporan. Dan kalau di akhir tahun juga sering trouble gara-gara banyak yang sedang melakukan input di sistem."

Risiko kecurangan lain pada tahap penatausahaan berdasarkan hasil wawancara terjadi ketika di akhir tahun anggaran dana desa sering sekali terjadi gangguan maupun eror di SISKEUDES karena banyak user yang menggunakannya untuk melakukan input data realisasi anggaran di setiap daerah. Selain itu risiko pemadaman listrik oleh PLN serta jaringan internet yang tidak stabil mengharuskan bendahara desa mengerjakan penatausahaan di rumah supaya tidak terlambat dalam pelaporannya kepada bupati melalui camat. Sebagai bentuk pengendaliannya, semua hal yang berkaitan dengan penatausahaan oleh bendahara desa dilakukan setiap kali terdapat proyek kegiatan pembangunan yang telah selesai, sehingga tidak perlu menunggu sampai akhir tahun anggaran dana desa kemudian baru melakukan input data di SISKEUDES. Kegiatan penatausahaan dikerjakan di kantor desa dengan monitoring serta otorisasi langsung dari kepala desa, supaya dapat meminimalisir adanya manipulasi data oleh bendahara desa yang tidak sesuai dengan APBDes serta bukti kegiatan realisasi di lapangan.

"kalau di tahap pelaporan aman sih, Mas. Karena selama ini kita juga belum pernah mengalami keterlambatan. Cara menyiasatinya kita membuat timeline khusus diluar pemerintah pusat supaya ndak terlambat dan sekarang pun pemerintah daerah pintar kalau belum melaporkan laporannya gajinya ya ndak cair."

Pada tahap pelaporan tidak ditemukan risiko kecurangan sesuai dengan pernyataan dari kepala desa dan bendahara desa. Pelaporan yang 
disampaikan oleh kepala desa kepada kabupaten melalui camat tidak pernah mengalami keterlambatan. Hal ini didukung dengan pengendalian yang telah dilaksanakan yaitu: (1) perangkat desa menetapkan timeline khusus untuk melaporkan hasil pengelolaan dana desa kepada bupati melalui camat selama satu tahun anggaran sebelum batas yang sudah ditetapkan oleh pemerintah pusat, (2) menjadikan laporan pertanggungjawaban pengelolaan dana desa sebagai salah satu syarat penerimaan gaji bagi perangkat desa didukung dengan surat serah terima dari desa ke kecamatan.

Pada tahap pertanggungjawaban, risiko kecurangan yang mungkin terjadi adalah penyalahgunaan wewenang perangkat desa dalam laporan pertanggungjawaban baik kepada kabupaten maupun masyarakat yang tidak sesuai dengan APBDes, realisasi yang terjadi di lapangan, serta data yang diinput dalam SISKEUDES.

"BPD, dan masyarakat hanya memastikan semua pembangunan desa sudah selesai atau belum sampai akhir tahun anggaran. Perangkat desa hanya bertugas menginformasikan kepada masyarakat bahwa perencanaan di awal periode telah terlaksana seluruhnya."

Hal yang dilakukan perangkat desa sebagai bentuk pengendalian adalah membuat sebuah forum diskusi yang dihadiri oleh BPD sebagai dewan pengawas, ketua RT, ketua RW, kepala dusun dan perwakilan dari masyarakat lainnya untuk membahas laporan pertanggungjawaban serta evaluasi dari setiap rencana yang sudah ditetapkan dengan hasil realisasi pembangunan desa yang telah dilakukan selama satu tahun anggaran dengan menampilkan SISKEUDES sebagai buktinya. Selain itu, melakukan pertanggungjawaban kepada bupati melalui camat berupa SPJ dengan bukti kegiatan, serta kepada masyarakat dengan memasang MMT rencana maupun realisasi anggaran dana desa di tempat strategis, melakukan update data di website Desa Kebonan, menyebarkan flyer dan buku LPPD yang berisikan tentang pembangunan yang telah dilakukan desa selama satu periode di rapat-rapat RT melalui ketua RT.

\section{Kearifan Lokal sebagai Pengendali dan Pemitigasi Risiko Kecurangan}

Salah satu hal yang bisa dipakai untuk menambah kuatnya pengendalian pengelolaan dana desa di Desa Kebonan adalah kearifan lokal. Beberapa bentuk kearifan lokal yang ada di Desa Kebonan yaitu merti desa, sadranan, dan ewuh pekewuh. Pertama, merti desa. Kearifan lokal ini dilakukan secara rutin oleh Desa Kebonan setiap dua tahun sekali di hari pasaran yaitu Sabtu Kliwon dan Minggu Legi menurut kalender Jawa. Rangkaian merti desa dimulai dengan masyarakat secara bergotong-royong membersihkan lingkungan sekitar desa dilanjutkan dengan acara wayang kulit dan berdoa bersama. Pernyataan ini sesuai dengan kutipan wawancara sebagai berikut:

"merti desa itu diadakannya setiap dua tahun sekali, Mas. Acaranya ya bersihbersih desa terus nanti bikin panggung untuk wayangan di malam harinya. Dan itu ya dilakukan sampai sekarang supaya desa dijauhkan dari memala kalau kata orang Jawa."

Nilai merti desa yang diyakini oleh masyarakat adalah supaya desa dijauhkan dari hal-hal negatif dan apabila setiap ritual tidak dijalankan maka desa akan menerima malapetaka di masa yang akan datang. Jika nilai yang terkandung di dalam merti desa dikaitkan dengan pengendalian pengelolaan dana desa maka merti desa dapat mencegah perangkat desa untuk melakukan hal-hal negatif pada masyarakat desa seperti tindakan korupsi, kolusi dan nepotisme.

"terus ada lagi itu sadranan, sebenarnya kalau lebih mau tahu artinya ya ke juru kuncinya. Tapi secara garis besar kalau merti desa bersih-bersih desa, kalau sadranan bersihinnya makammakam para leluhur. Setelah itu masyarakat kan membawa makanan tuh, sekalian didoakan dan dimakan bersama di 
makam itu juga. Artinya ya itu menandakan kebersamaan di masyarakat Kebonan dan mendoakan leluhur supaya ditempatkan di tempat yang terbaik."

Kedua, sadranan di Desa Kebonan dilakukan setiap setahun dua kali pada pertengahan bulan Ruwah menurut kalender Jawa dengan ritual membersihkan makam di sekitar desa kemudian melakukan doa bersama. Hal tersebut mengandung makna penghormatan kepada leluhur yang dianggap memiliki peran penting semasa hidupnya bagi desa dan keluarga dari masyarakat yang telah meninggal supaya diberikan pengampunan serta mendapatkan tempat yang terbaik. Selain itu, berdoa bagi desa supaya dilimpahkan rezeki serta dijauhkan dari hal-hal buruk. Dalam ritual sadranan, setiap keluarga wajib membawa makanan seperti nasi, lauk pauk berserta sayur untuk dimakan bersama dengan masyarakat Desa Kebonan lainnya sebagai wujud ucapan syukur atas berkat yang diberikan Tuhan dan rasa saling menghormati antar masyarakat desa. Apabila nilai yang terkandung di dalam sadranan dijiwai dan diimplementasikan dalam pengelolaan dana desa sebagai bentuk pengendalian maka timbul adanya rasa kebersamaan dalam membangun desa dengan orientasi utamanya pada masyarakat, sehingga tidak boleh hanya digunakan untuk kepentingan sepihak saja. Selain itu, desa menjadi aman dari hal buruk yang dapat mendatangkan malapetaka bagi masyarakat desa seperti memprioritaskan kepentingan golongan, manipulasi data, dan korupsi karena setiap tugas dan fungsi perangkat desa diawasi oleh para leluhur.

"disini juga masih ada budaya sopan santunnya, Mas. Ewuh pekewuhnya ke orang yang lebih tua itu tetap ada. Karena misalkan kita mau banyak omong dengan orang yang lebih tua kan dikiranya menggurui, mending ndak. Rasa ndak enakan itu masih ada. Dalam diskusi pun tetap menang yang tua. Hal sederhana seperti itu sih Mas. Apalagi kan mau melakukan hal-hal yang salah. Kalau ada kesalahan pun harus ada buktinya dulu baru ngomong."

Ketiga, ewuh pekewuh. Masyarakat Desa Kebonan masih menjiwai budaya Jawa yaitu ewuh pekewuh, perasaan sungkan untuk melakukan hal-hal yang bertentangan dengan norma yang berlaku. Selain itu, merupakan salah satu tindakan hormat kepada orang yang lebih tua karena dianggap memiliki pengalaman dan pengetahuan lebih. Kaitannya nilai yang terkandung dalam ewuh pekewuh dengan pengendalian risiko kecurangan pada pengelolaan dana desa yaitu adanya sikap toleransi pada setiap kebutuhan masyarakat sebagai wujud saling menghormati antar masyarakat desa serta sebagai sarana pengingat forum diskusi ketika terdapat hal yang tidak sesuai dengan kebutuhan masyarakat maupun peraturan yang berlaku.

\section{Pembahasan}

Berdasarkan hasil wawancara dengan seluruh narasumber, dapat dilihat bahwa pengelolaan dana desa di Desa Kebonan pada tahap perencanaan, pelaksanaan, penatausahaan, dan pertanggungjawaban masih menunjukkan adanya risiko kecurangan. Pada tahap perencanaan, risiko yang dapat terjadi disebabkan oleh adanya kepentingan dari kelompok tertentu, regulasi dan aturan yang berlaku serta adanya kesan negatif dari masyarakat kepada perangkat desa karena dana desa masih dianggap hal baru dan rawan untuk disalah gunakan. Kemudian pada tahap pelaksanaan, risiko muncul karena TPK dari masyarakat dinilai tidak dapat menjalankan tugasnya dengan maksimal, adanya kesempatan memanipulasi bukti transaksi pembangunan desa yang tidak sesuai dengan RAB dan RKPDes serta adanya potensi keterlambatan pembangunan infrastruktur karena implementasi tahapan pencairan dana desa yang tidak sesuai dengan kebutuhan. Selanjutnya pada tahap penatausahaan yang dilakukan oleh bendahara desa, risiko yang dapat terjadi adalah manipulasi data dalam SISKEUDES serta deadline yang padat di akhir tahun 
anggaran dana desa yang mengharuskan bendahara desa melakukan penatausahaan di rumah. Pada tahap pertanggungjawaban, risiko kecurangan dikarenakan adanya penyalahgunaan wewenang oleh perangkat desa.

Secara keseluruhan apabila risiko kecurangan pengelolaan dana desa di Desa Kebonan dikaitkan dengan fraud triangle, maka kesempatan menjadi faktor penyebab utama di dalamnya. Hal ini ditunjukkan dengan adanya risiko perangkat desa menyalahgunakan jabatannya untuk melakukan tindak kecurangan, keterlambatan pencairan dana desa pada tahap awal yang berpengaruh pada pembuatan laporan realisasi anggaran yang tidak sesuai dengan sebenarnya supaya dapat mencairkan dana desa di tahap selanjutnya, serta deadline yang padat di akhir tahun anggaran yang membuat laporan pertanggungjawaban harus dikerjakan di rumah.

\begin{abstract}
Kearifan lokal dapat dipakai sebagai salah satu alat pemitigasi risiko kecurangan jika filosofinya dijiwai dan diimplementasikan dengan baik. Sejauh ini kearifan lokal yang ada di Desa Kebonan, seperti merti desa, sadranan, dan ewuh pekewuh secara rutin terus dilaksanakan, namun kearifan lokal yang ada belum benar dijiwai jika dikaitkan dengan pengelolaan dana desa. Hal tersebut terlihat ketika masyarakat Desa Kebonan melaksanakan kearifan lokal hanya menjadi sebuah tradisi yang wajib dilakukan setiap tahun, namun dalam pelaksanaannya masyarakat kurang memahami tentang filosofi dan nilai yang terkandung. Masyarakat hanya memaknai secara umum bahwa ketika kearifan lokal tidak dilakukan, maka desa akan menerima malapetaka.
\end{abstract}

\section{KESIMPULAN}

Secara umum, pengelolaan dana desa di Desa Kebonan sudah mengikuti alur pengelolaan dana desa yang disyaratkan dalam Permendagri No.20 Tahun 2018. Adapun di dalam implementasi di setiap tahapannya terdapat risiko-risiko kecurangan, seperti adanya kepentingan dari kelompok tertentu, regulasi dan aturan yang berlaku sehingga mengakibatkan benturan kepentingan, kesan negatif dari masyarakat, memanipulasi bukti transaksi pembangunan desa yang tidak sesuai dengan RAB dan RKPDes, TPK dari masyarakat dinilai tidak dapat menjalankan tugasnya dengan maksimal, manipulasi data dalam SISKEUDES serta deadline yang padat di akhir tahun anggaran dana desa yang mengharuskan bendahara desa melakukan penatausahaan di rumah, penyalahgunaan wewenang oleh perangkat desa. Meskipun di setiap risiko sudah terdapat bentuk pengendalian untuk dapat mengurangi dan mengelola risiko tersebut, namun kearifan lokal dirasa dapat juga dipakai sebagai sarana pemitigasi risiko kecurangan jika dijiwai dengan baik. Namun yang terjadi di Desa Kebonan, kearifan lokal seperti merti desa, sadranan, dan ewuh pekewuh sejauh ini hanya dijiwai sebagai tradisi turun-temurun tanpa lebih lanjut mengambil nilai atau filosofi yang lebih dalam implementasi pengelolaan dana desa.

\section{IMPLIKASI KETERBATASAN}

DAN

Implikasi dari hasil penelitian ini adalah mendorong masyarakat untuk terus melestarikan kearifan lokal yang ada karena melihat dampak positif dari kearifan lokal dalam memitigasi risiko kecurangan pengelolaan keuangan desa. Selain itu, dapat dijadikan sarana evaluasi pengendalian internal perangkat desa dan masyarakat supaya lebih bijaksana dalam mengelola keuangan desa dan dapat digunakan secara optimal.

Keterbatasan dalam penelitian ini adalah narasumber yang dianggap sebagai juru kunci kearifan lokal Desa Kebonan dan sesepuh desa tidak dapat diwawancarai karena masalah kesehatan. Selain itu, perkembangan teknologi saat ini membuat masyarakat menjadi lebih modern sehingga kearifan lokal hanya dilakukan sebagai sebuah tradisi turun-temurun dari 
nenek moyang tanpa menghayati nilai yang terkandung di dalamnya.

Penelitian selanjutnya diharapkan dapat dilakukan menggunakan metode kuantitatif seperti menguji pengaruh implementasi filosofi kearifan lokal terhadap niat untuk melakukan whistleblowing. Selain itu, penelitian mendatang tidak hanya dilakukan di Jawa Tengah melainkan di setiap daerah yang ada di Indonesia, karena setiap daerah memiliki nilai kearifan lokal sendiri sehingga tidak dapat menggeneralisasikannya di daerah lain.

\section{REFERENCES}

Abidin, M. Z. (2015). Tinjauan Atas Pelaksanaan Keuangan Desa dalam Mendukung Kebijakan Dana Desa. Jurnal Ekonomi \& Kebijakan Publik, 6(1), $\quad$ 61-76. https://doi.org/http://dx.doi.org/10.2221 2/jekp.v6i1.156

Adzkia, A. (2019). Dana Desa Ladang Basah Korupsi Dana Desa. Beritagar. https://beritagar.id/artikel/berita/ladang -basah-korupsi-dana-desa

Amalia, A. D., \& Syawie, M. (2015). Pembangunan Kemandirian Desa Melalui Konsep Pemberdayaan: Suatu Kajian dalam Perspektif Sosiologi. Jurnal Kementerian Sosial Republik INdonesia, 175-188.

Association of Certified Fraud Examiners. (2018). Survei Fraud Indonesia. Auditor Essentials, 7-10. https://doi.org/10.1201/978131517814 $1-3$

Atmadja, A. T., \& Saputra, A. K. (2017). Pencegahan Fraud dalam Pengelolaan Keuangan Desa. Jurnal IImiah Akuntansi Dan Bisnis, 1, 7. https://doi.org/10.24843/jiab.2017.v12. i01.p02

Badan Pengelolaan Keuangan dan Aset. (2016). Tahapan Pengelolaan Keuangan Desa. https://www.google.com/search?safe=
strict\&rlz=1C1GCEA enID851ID851\& biw $=1366 \& b i h=657 \&$ tbm $=$ isch \&sa $=1 \&$ $\mathrm{e}=4 \mathrm{c} 4 \mathrm{zXeq} 4 \mathrm{O} 5 \mathrm{eVwgP74b2ACQ \& q=5}$ +Tahapan+Pengelolaan+Keuangan+D esa.\&oq $=5+$ Tahapan + Pengelolaan $+\mathrm{K}$ euangan+Desa.\&gs_l=img.3...7737.78 64..8258...0.0..0.183.302.0j2...

Cressey, D. (1953). Other People's Money: a Study in the Social Psychology of Embezzlement. IL: Free Press.

Darmada, D. K., Atmadja, A. T., \& Sinarwati, N. K. (2015). Pade Gelahang Sebagai Kearifan Budaya Lokal Untuk Mewujudkan Integrasi Dalam Akuntabilitas Pengelolaan Keuangan Organisasi Subak (Studi Fenomena Pada Subak Multikultur di Desa Penarukan Kecamatan Buleleng, Kabupaten Buleleng, Provinsi Bali). Jurnal Ilmiah Mahasiswa Akuntansi Universitas Pendidikan Ganesha, 3.

Fajarini, U. (2014). Peranan Kearifan Lokal Dalam Pendidikan Karakter. Jurnal Sosio Didaktika: Social Science Education Journal, 1(2). https://doi.org/10.15408/sd.v1i2.1225

Fajri, Setyowati, E., \& Siswidiyanto. (2015). Akuntabilitas Pemerintah Desa pada Pengelolaan Alokasi Dana Desa (Studi Pada Kantor Desa Ketindan, Kecamatan Lawang, Kabupaten Malang). Jurnal Elektronik Mahasiswa Jurusan Administrasi Publik Universitas Brawijaya, 3(7), 10991104.

Fauzi, I. (2019). Membongkar Misteri Desa Siluman. Retrieved from Kumparan News website: https://kumparan.com/kumparannews/ membongkar-misteri-desa-siluman1sEPlodiKI2

Ihsanuddin. (2018). ICW: Ada 181 Kasus Korupsi Dana Desa, Rugikan Negara Rp 40,6 Miliar. Kompas.Com. https://nasional.kompas.com/read/201 8/11/21/19000481/icw-ada-181-kasuskorupsi-dana-desa-rugikan-negara-rp406-miliar?page=all 
Islami, M. E. N. (2014). Simbol dan Makna Ritual Yaqowiyu di Jatinom Klaten. Jurnal Media Wisata, 12(2), 102-115.

Kementerian Keuangan Republik Indonesia. (2017). Buku Saku Dana Desa. Dana Desa untuk Kesejahteraan Rakyat. 7.

Komisi Pemberantasan Korupsi. (2018). Kasus Korupsi di Indonesia Tahun 2004-2018. https://acch.kpk.go.id/id/

Muliana, V. A. (2018). Daftar Negara Paling Korup di Asia Pasifik, Indonesia Nomor Berapa? Liputan 6. https://www.liputan6.com/bisnis/read/3 313605/daftar-negara-paling-korup-diasia-pasifik-indonesia-nomorberapa? related $=$ dable\&utm_expid $=.9 \mathrm{Z}$ 4i5ypGQeGiS7w9arwTvQ.1\&utm_refe rrer $=$

Pattinama, M. J. (2009). Poverty Reduction through Local Wisdom. Jurnal Makara, Sosial Humaniora, 13(1), 1-12.

Pawarti, A., Purnaweni, H., Didi, D., Anggoro, D., Magister, M., Lingkungan, I., Bkd, S., Dharmasraya, K., \& Sumatera Barat, P. (2012). Nilai Pelestarian Lingkungan dalam Kearifan Lokal Lubuk Larangan Ngalau Agung di Kampuang Surau Kabupaten Dharmasraya Provinsi Sumatera Barat. Prosiding Seminar Nasional Pengelolaan Sumberdaya Alam Dan Lingkungan, September, 98-103.

http://eprints.undip.ac.id/37597/1/017Amin_Pawarti_edited.pdf

Pemerintah Desa Kebonan. (2017). Peta Penggunaan Lahan Desa Kebonan, Kecamatan Karanggede, Kabupaten Boyolali. Retrieved from https://desakebonan.site/page/detail/peta-desa-

Peraturan Menteri Dalam Negeri No. 20 Tahun 2018 Tentang Pengelolaan Keuangan Desa, 72 Physical Review B 1 (2018).

Peraturan Pemerintah No. 43 Tahun 2014 Tentang Desa, 6 (2014). https://doi.org/10.1590/s1809

98232013000400007

Peraturan Pemerintah No. 8 Tahun 2016 Tentang Dana Desa, (2016).

Permana, R. C. E., Nasution, I. P., \& Gunawijaya, J. (2018). Kearifan Lokal Tentang Mitigasi Bencana Pada Masyarakat Baduy. Makara Human Behavior Studies in Asia, 15(1), 67. https://doi.org/10.7454/mssh.v15i1.95 4

Undang-Undang No. 6 Tahun 2014 Tentang Desa, 45 (2016). https://doi.org/10.1145/2904081.2904 088

Rahayu, D., Rahmayati, A., \& Narulitasari, D. (2018). Determinan Pencegahan Fraud Pengelolaan Keuangan Desa. Jurnal IImiah Among Makarti, 11, 97107.

Saputra, Putu Budi Anggiriawan, I Nyoman Sutapa, K. A. K. (2018). Akuntabilitas Pengelolaan Keuangan Desa Dalam Perspektif Budaya Tri Hita Karana. Jurnal Riset Akuntansi Dan Bisnis Airlangga, 3(1), 306-321. https://doi.org/10.31093/jraba.v3i1.90

Sartini. (2004). Menggali Kearifan Lokal Nusantara Sebuah Kajian Filsafati. Jurnal Filsafati, Fakultas Filsafat, Universitas Gadjah Mada, 14. https://journal.ugm.ac.id/wisdom/articl e/view/33910/20262

Sulistyaningsih, C., \& Badraningsih. (2017). Makna Simbolik Makanan Pada Upacara Tradisional Pager Bumi Rebo Wekasan di Dusun Puesari, Sleman. Jurnal Universitas Negeri Yogyakarta, 3-11.

Taufik, T. (2013). Pengelolaan Keuangan Desa dalam Sistem Keuangan Negara Republik Indonesia. Jurnal Jurusan Akuntansi Fakultas Ekonomi Universitas Riau, 17(1), 1-11. http://download.portalgaruda.org/articl e.php?article $=31387 \&$ val $=2268$

Wenden, A. L. (2011). Peran Badan 
Permusyawaratan Desa (BPD) dalam

Pengelolaan Dana Desa. Jurnal

Universitas Muhammadiyah

Surakarta, 3(September).

Wibisono, N. (2018). Mengungkap

Fenomena Pengawasan Publik

Terhadap Dana Desa Di Kabupaten

Madiun. Jurnal AKSI (Akuntansi Dan

Sistem Informasi), 1(2), 8-19.

https://doi.org/10.32486/aksi.v1i2.115 